Thorax (1976), 31, 167.

\title{
Squamous metaplasia of the tracheal epithelium in children
}

\author{
A VINASH MITHAL ${ }^{1}$ and JOHN L. EMER Y ${ }^{2}$ \\ The Chest Clinic, Lincoln ${ }^{1}$ and The Children's Hospital, Sheffield ${ }^{2}$
}

\begin{abstract}
Mithal, A. and Emery, J. L. (1976). Thorax, 31, 167-171. Squamous metaplasia of the tracheal epithelium in children. Thirty-seven $(1.6 \%)$ tracheas from 2170 children showed squamous metaplasia. (Cases with tracheo-oesophageal fistula and congenital heart disease were excluded.) The metaplasia extended into the bronchi in 15 cases. Features of pulmonary retention were present in seven cases. Respiratory infection, probably viral, seemed to be the most significant causative factor in 20 children, including those with cystic fibrosis. Tracheal instrumentation was a possible factor in 11 cases but oxygen therapy alone did not seem important. The metaplasia was almost certainly congenital in one child and probably in two others but no stillborn infants showed metaplasia. In many children the metaplasia seemed to be due to a combination of factors.
\end{abstract}

Squamous metaplasia of the trachea in childhood has been described in cases of measles (Goldzieher, 1918), influenza (Askanazy, 1919), cystic fibrosis of the pancreas (Zuelzer and Newton, 1949), and following intubation of the trachea (Rasche and Kuhns, 1972) and tracheostomy (Sara, 1967; Sara and Reye, 1969).

In a series of 50 children who died with tracheooesophageal fistula and were studied in this department, $80 \%$ had squamous metaplasia of the trachea and bronchi (Emery and Haddadin, 1971) and this was a major factor in at least 17 of these deaths. Retention lung, in which the alveoli are filled with colloid and cell debris, occurred in over half of these children (Haddadin and Emery, 1971). Sara and Reye (1969) found squamous metaplasia in $13(6 \%)$ of 203 sequential child deaths in Australia.

Apart from children with tracheo-oesophageal fistula, we had not been impressed by the incidence of metaplasia in routine necropsies; thus, a consecutive series of over 2000 necropsies on children have been surveyed to assess the incidence of metaplasia, the conditions leading to it, and possible clinical implications of the lesion.

\section{MATERIALS AND METHODS}

Routine necropsy practice at Sheffield Children's Hospital includes a block from the unopened trachea half way from the larynx to the carina.
Tracheas from children with tracheo-oesophageal fistula and those with congenital heart disease or other gross deformities were excluded. There were thus 2331 tracheas available for study. Epithelium was absent in 16 cases. This left 2170 tracheas for histological analysis.

Squamous metaplasia was diagnosed, as in a former study (Emery and Haddadin, 1971), when ciliated epithelium was absent and replaced by cells with longitudinal axis parallel to the basement membrane (Fig. 1). Goblet cells were also absent. The lung sections from those with squamous metaplasia were surveyed and the clinical details reviewed.

\section{RESULTS}

Squamous metaplasia was seen in $37(1.6 \%)$ of the 2170 tracheas. They fell into five clinical groups. Six had undergone a tracheostomy or intubation. Four died postoperatively. Viral or bacterial infection occurred terminally in eleven. Cystic fibrosis was present in eight. The remaining eight died from miscellaneous conditions.

Of the six children who underwent tracheal instrumentation, four had tracheostomies lasting from 1 to 14 days. The two remaining infants were intubated for 8 hours and three days respectively (Table I). The underlying conditions varied. One had meningomyelocele and one had Haemophilus influenzae meningitis. Cystic hygroma in 


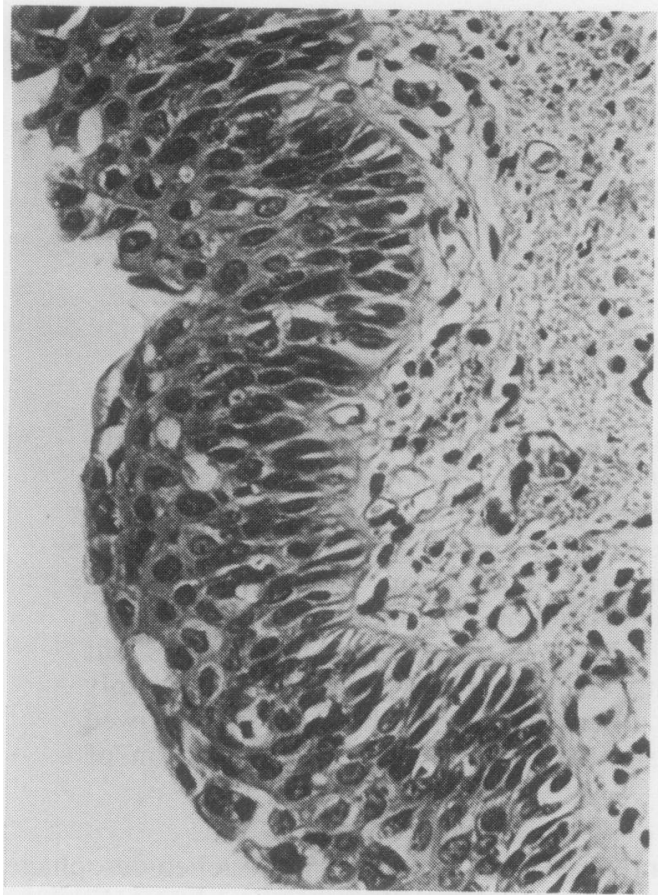

FIG. 1. Squamous metaplasia: ciliated columnar epithelium is replaced by cells with longitudinal axis parallel to the basement membrane.

the neck was present in three (out of a total of seven in the whole series). One had a large diaphragmatic hernia; because of respiratory distress, he was intubated and transferred to the surgical unit and operated upon. The tracheal tube remained in situ until death at the age of 8 hours. Only one of these six children had histological evidence of infection. The only child in this group showing retention lung (Fig. 2) also had metaplasia of the bronchial epithelium. He had a tracheostomy only 24 hours before death.

The postoperative group of four children all received oxygen after operation but had no

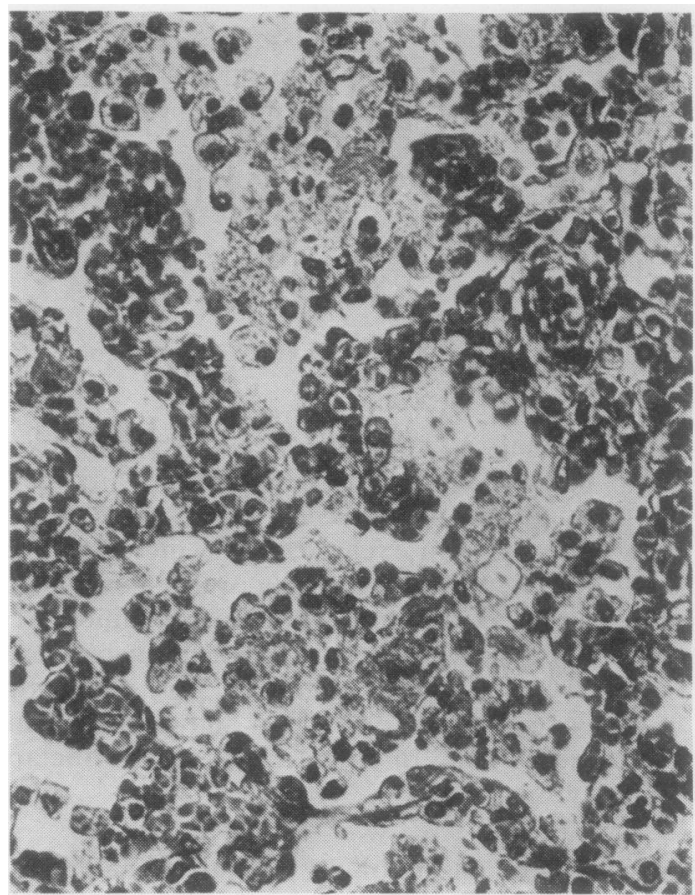

FIG. 2. Retention lung: the alveolar spaces are filled with colloid and cell debris.

tracheal instrumentation. Death occurred from one day to six months after operation. Three of these had suspected or proven Hirschsprung's disease; these three had retention lungs and the fourth had meningomyelocele (Table II).

The ages of the 11 children with respiratory infections ranged from 6 weeks to 4 years. Swabs from one grew $\boldsymbol{H}$. influenzae, and Staphylococcus aureus was grown from another. The remaining nine showed evidence of a viral infection histologically. Metaplasia of epithelium extended into the bronchi in six cases, all of whom had been ill for from three to 28 days. Retention lung was noted in two of these.

T A B L E I

TRACHEOSTOMY/INTUBATION

\begin{tabular}{|c|c|c|c|c|c|}
\hline Age & Sex & $\begin{array}{c}\text { Tracheostomy/Intubation } \\
\text { (Duration) }\end{array}$ & Underlying Disease & Bronchial Histology & Lung Histology \\
\hline $5 \mathrm{mth}$ & $\mathbf{M}$ & Tracheostomy (5 days) & $\begin{array}{l}\text { Meningomyelocele/ } \\
\text { hydrocephalus }\end{array}$ & $\begin{array}{l}\text { Acute purulent } \\
\text { bronchitis }\end{array}$ & Pulmonary oedema \\
\hline $\begin{array}{l}10 \mathrm{mth} \\
5 \mathrm{~d} \\
3 \mathrm{~d} \\
5 \mathrm{wk}\end{array}$ & $\begin{array}{l}\mathbf{F} \\
\mathbf{M} \\
\mathbf{M} \\
\mathbf{M}\end{array}$ & $\begin{array}{l}\text { Intubation (3 days) } \\
\text { Tracheostomy (1 day) } \\
\text { Tracheostomy (2 days) } \\
\text { Tracheostomy (14 days) }\end{array}$ & $\begin{array}{l}\text { Haemophilus meningitis } \\
\text { Cystic hygroma (R) } \\
\text { Cystic hygroma (L) } \\
\text { Cystic hygroma (L) }\end{array}$ & $\begin{array}{l}\text { Normal } \\
\text { Metaplasia } \\
\text { Normal } \\
\text { Normal }\end{array}$ & $\begin{array}{l}\text { Patchy areas of collapse } \\
\text { Retention lung } \\
\text { Interstitial oedema } \\
\text { Peripheral alveolar }\end{array}$ \\
\hline $8 \mathrm{~h}$ & $\mathbf{M}$ & Intubation ( 8 hours) & Diaphragmatic hernia (L) & Not available & Not available \\
\hline
\end{tabular}


T A B L E I I

POSTOPERATIVE (GROUP 2)

\begin{tabular}{|c|c|c|c|c|}
\hline Age & Sex & Underlying Conditions & Bronchial Histology & Lung Histology \\
\hline $\begin{array}{l}4.5 \mathrm{mth} \\
4 \mathrm{mth} \\
1 \mathrm{yr} 5 \mathrm{mth} \\
11 \mathrm{mth}\end{array}$ & $\begin{array}{l}\mathbf{F} \\
\mathbf{M} \\
\mathbf{M} \\
\mathbf{M}\end{array}$ & $\begin{array}{l}\text { Lumbar meningomyelocele/hydrocephalus. } \\
\text { Died } 2 \text { days postoperatively on oxygen. } \\
\text { Hirschsprung's disease. Laparotomy at } \\
2 \text { months but repeated wound dehiscence. } \\
\text { Died } 12 \text { days later on oxygen. } \\
\text { Hirschsprung's disease. } \\
\text { Died } 1 \text { day postoperatively on oxygen. } \\
\text { Hirschsprung's disease } \\
\text { Laparotomy at } 2 \text { days and Duhamel's operation } \\
\text { at } 5 \text { months. } \\
\text { Re-admitted for observation but died suddenly- } \\
\text { not in intensive care. }\end{array}$ & $\begin{array}{l}\text { Hypertrophic bronchiolitis. } \\
\text { A little metaplasia. } \\
\text { Metaplasia } \\
\text { Bronchitis } \\
\text { Metaplasia }\end{array}$ & $\begin{array}{l}\text { Peripheral alveolar } \\
\text { collapse } \\
\text { Retention lung } \\
\text { Minimal retention } \\
\text { Retention lung }\end{array}$ \\
\hline
\end{tabular}

Out of a total of 26 children in the whole series who had cystic fibrosis, eight showed tracheal metaplasia. One of these was a twin and both twins died with abdominal distension at the age of 7 days. Only one had a laparotomy; the tracheal epithelium was normal in the twin who did not have an operation. Two of the eight cases with cystic fibrosis showed metaplasia of the bronchial epithelium also; they had been given continuous oxygen for four and seven days respectively.

The miscellaneous group of eight children had a variety of underlying clinical conditions. Two had jaundice from birth with the neonatal hepatitis syndrome, and bronchiolitis was present in one of these. One had congenital hypothyroidism and a viral infection terminally. Two had received antimitotic drugs, one for neuroblastoma and the other for leukaemia; retention lung was seen in the child with leukaemia. A 19-month-old epileptic infant died one week after smallpox vaccination and histological appearances suggested viral infection. The seventh case was a mentally retarded boy aged 3 years. He died with a chronic suppurative otitis media and osteomyelitis of the femur. The eighth died at the age of only 27 hours. This child was born at 39 weeks to a primagravida by forceps. He was normal at birth and weighed $3.240 \mathrm{~kg}$. Three hours later the child became cyanosed on crying, the cyanosis became persistent an hour later, and blood gases showed hypoxia and hypercapnia. He was, therefore, nursed in an incubator but died at the age of 27 hours. The trachea and bronchi were lined by a layer of mucus but there was no inflammatory reaction.

\section{DISCUSSION}

Following any condition that destroys the tracheal mucosa, whether it be chemical, mechanical or inflammatory, there is a rapid replacement seen as an extension of cells from the gland ducts over the denuded basement membrane. These cells are only two, or at most three, deep, are not ciliated, and are an extremely common finding at necropsy in infants following surgery or in those who have required any resuscitation procedures. We did not include such cases in our classification of tracheas with metaplasia. Our discussion here is concerned with tracheal epithelium which seems to have gone beyond the normal replacement situation, ie, where the replacement or maturation mechanisms of the epithelium are abnormal, or there is some continuing factor such as viral infection that prevents the normal development of a ciliated cover.

Tracheas from 2170 routine necropsies on infants and children, excluding those with tracheooesophageal fistula or congenital heart disease, showed squamous metaplasia in 37-an incidence of $1.6 \%$. Sara and Reye (1969) studied 203 babies and found only five with squamous metaplasia, of whom two had congenital heart disease. If these two are excluded, the incidence of squamous metaplasia is $1.5 \%$, which is remarkably similar to the $1.6 \%$ in our series.

The ages of our cases ranged from 8 hours to 9 years. Metaplasia was not found in any of the 200 stillbirths. Weller (1953) also did not find metaplasia in an unspecified number of stillbirths in his series. Our child who died at 8 hours is the youngest reported with tracheal metaplasia.

Of the factors producing squamous metaplasia, smoking is by far the most important in adults (Auerbach et al., 1960) but, in infants, possible factors include direct trauma during intubation, oxygen therapy, viral infection, cystic fibrosis, and a developmental anomaly.

Squamous metaplasia due to instrumentation of the trachea was described by Sara (1967). Sara and Reye (1969) considered that instrumentation of short duration did not cause metaplasia, and 
Rasche and Kuhns (1972) found that the endotracheal tube had to be in for at least five days before squamous metaplasia occurred. In our series, only two children had an endotracheal tube for five days or longer. Duration of instrumentation alone is, therefore, an unlikely major factor in most of our cases.

The relation to viral infection is clearer. Metaplasia is known in measles (Goldzieher, 1918) and influenza (Askanazy, 1919). In our series, 11 children had a respiratory infection: two had measles and there was histological evidence of a viral infection in seven others. The remaining two had bacterial infections-Staph. aureus infection in one case and $H$. influenzae in the other. Metaplasia has not been noted in association with bacterial infections, but it is possible that our two children had a mixed bacterial and viral infection. Respiratory infection was noted in five of the eight children with cystic fibrosis. It was also present in four out of eight children in the miscellaneous group. Thus, infection affected 20 out of 37 children in this series.

Zuelzer and Newton (1949) noted metaplasia in children with cystic fibrosis. In our eight cases with cystic fibrosis, additional possible factors such as oxygen therapy for at least four days, or infection, were present and one child died within 24 hours of laparotomy (Table III).

The relation between tracheal metaplasia and oxygen therapy is difficult to evaluate. A review of the literature does not suggest any connection. Oxygen therapy was not related to metaplasia in cases of tracheo-oesophageal fistula (Emery and Haddadin, 1971). Our present series also shows no direct relation to oxygen therapy but the concentration of oxygen given was often not known.

Among our miscellaneous group, infection was present in four of the eight children. One known epileptic died in status epilepticus one week after smallpox vaccination, and histology of the lung suggested a viral infection. Cytotoxic drugs may have induced tracheal metaplasia in two children, but there were, in our series, 22 other children who had been treated with cytotoxic drugs and showed no squamous metaplasia.

It is possible that squamous metaplasia may occur as a congenital deformity but this is difficult to assess. Trauma or infection needs to operate for some days at least for metaplasia to occur. Three of our children had instrumentation for three days or less and one for only the eight hours that he lived. In these cases, it is tempting to suggest that the metaplasia is congenital, but no metaplasia was noted in the 200 stillbirths in this series. With an incidence of $1.65 \%$, at least three of the 200 stillbirths should have shown tracheal metaplasia. We have no knowledge of how rapidly squamous metaplasia can occur. In the child who died at the age of 8 hours, the metaplasia may have been present at birth, and the two children who died after only a short period of intubation may also have had congenital metaplasia.

Pulmonary retention characterized by consolidated lungs and alveoli filled, not with an inflammatory exudate, but with colloid and cell debris, occurs in cases of tracheal-oesophageal fistula. In 17 of 31 such cases, pulmonary retention was thought to be the main cause of death (Haddadin and Emery, 1971). This condition was present in

T A B L E I I I

CYSTIC FIBROSIS

\begin{tabular}{|c|c|c|c|c|c|}
\hline $\begin{array}{l}\text { No. of } \\
\text { Cases }\end{array}$ & Age & Sex & Clinical Details & Bronchial Histology & Lung Histology \\
\hline 3 & $\begin{array}{l}2 \text { yr } 3 \mathrm{mth} \\
10 \mathrm{~d} \\
7 \mathrm{~d}\end{array}$ & $\begin{array}{l}\mathbf{M} \\
\mathbf{F} \\
\mathbf{M}\end{array}$ & $\begin{array}{l}\text { Laparotomy for abdominal } \\
\text { distension }\end{array}$ & $\begin{array}{l}\text { Purulent bronchiolitis } \\
\text { Purulent bronchiolitis } \\
\text { Metaplasia } \\
\text { Normal }\end{array}$ & $\begin{array}{l}\text { Lymphoreticular aggregates } \\
\text { No significant abnormality } \\
\text { Hyaline membrane atelectasis }\end{array}$ \\
\hline 2 & $\begin{array}{l}6 \mathrm{wk} \\
11 \mathrm{wk}\end{array}$ & $\begin{array}{l}\mathbf{F} \\
\mathbf{M}\end{array}$ & $\begin{array}{l}\text { Severe respiratory distress. } \\
\text { Given oxygen for } 4 \text { days and } \\
1 \text { week respectively }\end{array}$ & $\begin{array}{l}\text { Loss of cilia } \\
\text { Metaplasia } \\
\text { Chronic bronchiolitis }\end{array}$ & $\begin{array}{l}\text { Massive alveolar haemorrhage } \\
\text { Pulmonary oedema } \\
\text { Foci of necrosis } \\
\text { No significant abnormality }\end{array}$ \\
\hline 1 & 7 wk & $\mathbf{M}$ & $\begin{array}{l}\text { Progressive abdominal } \\
\text { distension }\end{array}$ & $\begin{array}{l}\text { Chronic bronchiolitis } \\
\text { A little metaplasia }\end{array}$ & Terminal bronchopneumonia \\
\hline 1 & $5 \mathrm{mth}$ & $\mathbf{M}$ & $\begin{array}{l}\text { Feeding difficulty since birth } \\
\text { with failure to thrive. } \\
\text { Cyanotic attack before } \\
\text { admission }\end{array}$ & $\begin{array}{l}\text { Bronchiolitis } \\
\text { Metaplasia }\end{array}$ & Pulmonary retention \\
\hline 1 & $7 \mathrm{mth}$ & $\mathbf{M}$ & $\begin{array}{l}\text { One day history of cough with } \\
\text { respiratory distress }\end{array}$ & $\begin{array}{l}\text { Mucus lining all the bronchi } \\
\text { and bronchioles. } \\
\text { No metaplasia }\end{array}$ & $\begin{array}{l}\text { Massive pulmonary oedema but } \\
\text { no evidence of infection }\end{array}$ \\
\hline
\end{tabular}


the lungs of seven of our 37 cases, and, in six of these, metaplasia extended into the bronchi. Three of the seven had had a laparotomy for Hirschsprung's disease and the other four were associated respectively with infection, tracheostomy, cystic fibrosis, and leukaemia. Pulmonary retention can thus complicate a variety of conditions where squamous metaplasia involves the bronchi and prevents normal elimination of alveolar cellular debris; this seemed to be the chief factor in the death of seven of our children. No other significant pathological features were found in the lungs of the remaining 30 children and this is in keeping with the findings of Weller (1953) and Sara and Reye (1969).

One of us (AM) was aided by a research grant from The Trent Regional Health Authority. We are grateful to Mrs. Barbara Abbott for secretarial assistance.

\section{REFERENCES}

Askanazy, J. (1919). Ueber die Veränderungen der grossen Luftwege besonders ihre EpithelMetaplasie bei der Influenza. Correspondenzblatt für Schweizer Aerzte, 49, 465.

Auerbach, O., Stout, A. P., Hammond, E. C., and Garfinkel, L. (1960). Microscopic examination of bronchial epithelium in children. American $R e$ view of Respiratory Diseases, 82, 640.
Emery, J. L. and Haddadin, A. J. (1971). Squamous epithelium in respiratory tract of children with tracheo-oesophageal fistula. Archives of Disease in Childhood, 46, 236.

Goldzieher, M. (1918). Ueber basalzel Lenwucherungen der Bronchialschleimhaut. Zentralblatt fur allgemeine Pathologie und Pathologische Anatomie, 29, 506.

Haddadin, A. J. and Emery, J. L. (1971). Pulmonary retention simulating pneumonia as a cause of death in children with tracheo-oesophageal fistula. Surgery, 70, 2, 311.

Rasche, R. F. H. and Kuhns, L. R. (1972). Histopathologic changes in airway mucosa of infants after endotracheal intubation. Pediatrics, 50, 632.

Sara, C. A. (1967). Histological changes in the trachea and bronchi with tracheostomy. Medical Journal of A ustralia, 1, 1174.

and Reye, R. D. (1969). Epithelial changes in the trachea of children. Medical Journal of Australia, 2, 328 .

Weller, R. W. (1953). Metaplasia of bronchial epithelium. American Journal of Clinical Pathology, 23, 768.

Zuelzer, W. W. and Newton, W. A. Jr. (1949). The pathogenesis of fibrocystic disease of the pancreas: a study of 36 cases with special reference to the pulmonary lesion. Pediatrics, 4, 53.

Requests for reprints to: Professor J. L. Emery, The Children's Hospital, Sheffield. 